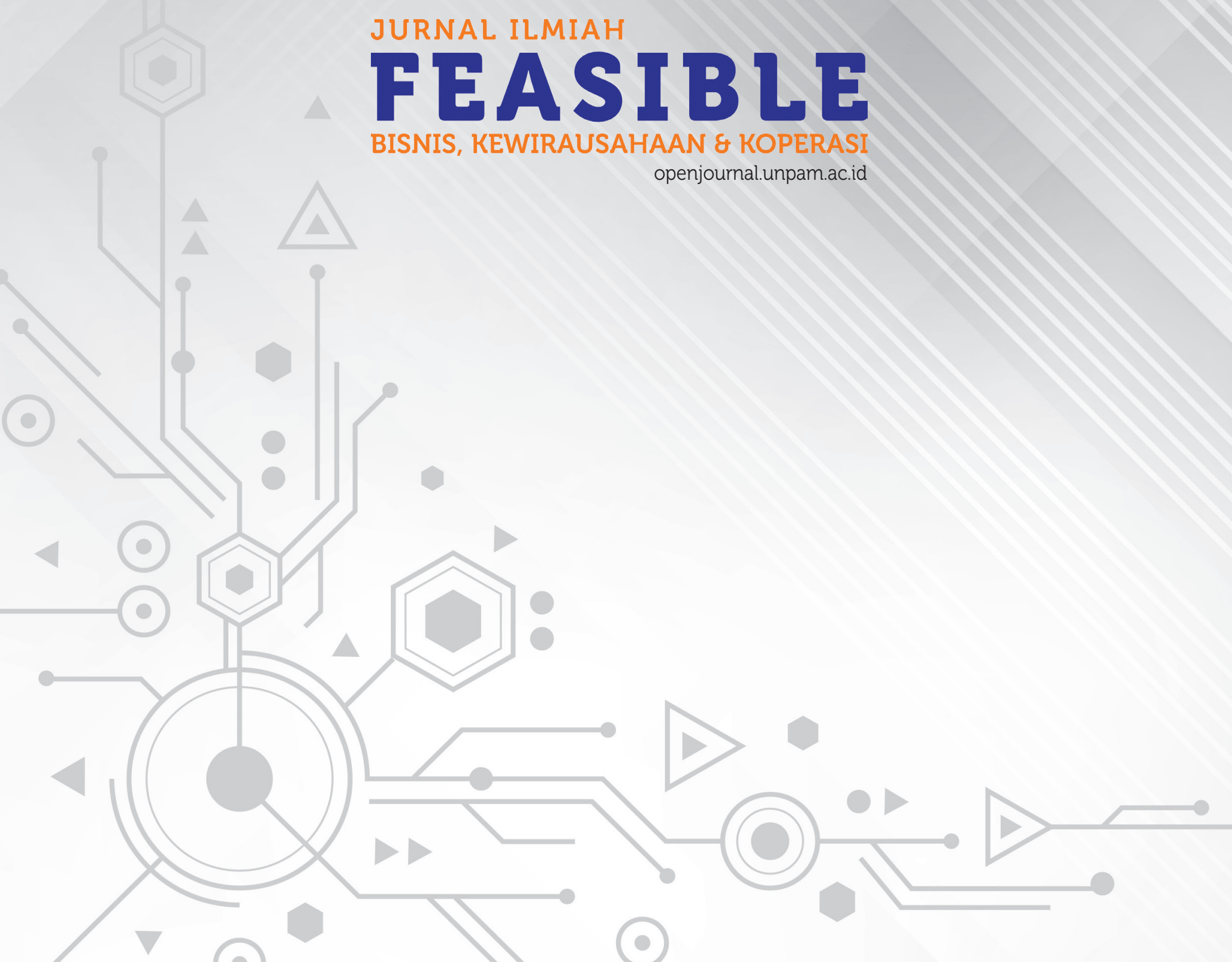




\title{
HUBUNGAN PENGETAHUAN ENTREPENEURSHIP DENGAN EFEKTIVITAS MANAJEMEN BERBASIS SEKOLAH (MBS)
}

\author{
Imas Masriah
}

\begin{abstract}
Abstrak
Penelitian ini bertujuan untuk mengetahui hubungan antara pengetahuan entrepreneurship kepala sekolah dengan efektivitas Manajemen Berbasis Sekolah pada sekolah-sekolah negeri unggulan tingkat SD di Kota Tangerang. Metode penelitian yang digunakan adalah motode survei dengan pendekatan korelational. Populasi dalam penelitian ini adalah para kepala SD Negeri yang sudah melaksanakan MBS yang terdapat di 13 kecamatan Kota Tangerang Banten. Sampel dalam penelitian ini 30 Kepala Sekolah yang diambil dengan teknik stratified proporsional sampling. Kalibrasi instrumen untuk uji validitas dengan korelasi point biserial dan uji reliabilitas dengan KR-2O. Sedangkan uji prasyarat, uji normalitas menggunakan uji lilifors dan uji homogenitas menggunakan uji Barlett. Dari hasil penelitian ditemukan terdapat hubungan yang positif antara pengetahuan entrepreneurship kepala sekolah dengan efektivitas MBS, artinya semakin tinggi pengetahuan entrepreneurship kepala sekolah, maka efektivitas MBS semakin tinggi pula. Bentuk persamaan regresi $\square=106,48+1,44 X$, dengan koefesien korelasi ry $=0,58$. Koefesien ini menunjukkan bahwa efeklivitas MBS dipengaruhi oleh pengetahuan entrepreneurship kepala sekolah sebesar $58 \%$.
\end{abstract}

Kata kunci: Entrepeneurship, Manajemen Berbasis Sekolah

\begin{abstract}
This research aims to determine the relationship between the knowledge of entrepreneurship of principals and the effectiveness of School-Based Management in primary schools in primary schools in the city of Tangerang. The research method used is a survey method with a correlational approach. The population in this study were the elementary school teachers who had implemented SBM in 13 sub-districts of Tangerang, Banten. The sample in this study were 30 Principals taken by the stratified proportional sampling technique. Instrument calibration to test validity with biserial point correlation and reliability test with $K R-2 O$. While the prerequisite test, the normality test uses the reliability test and the homogeneity test using the Barlett test. From the results of the study it was found that there was a positive relationship between the knowledge of entrepreneurship of the principal and the effectiveness of SBM, meaning that the higher the entrepreneurship knowledge of the principal, the higher the effectiveness of SBM. The form of the regression equation $\square=106.48+$ $1.44 X$, with correlation coefficient $r y=0.58$. This coefficient shows that the effectiveness of SBM is influenced by the principal's entrepreneurial knowledge of $58 \%$.
\end{abstract}

Keywords: Entrepeneurship, School Based Management

\section{PENDAHULUAN \\ Latar Belakang}

Mutu Pendidikan di Indonesia masih rendah di semua jenis dan jenjang pendidikan (Kompas No.267 Tahun ke-37, 30 Maret 2000), demikian juga masyarakat masih merasakan adanya standar mutu yang tidak jelas, ditambah dengan kesepakatan di tingkat kebijakan juga masih belum tercapai, yang berdampak pada iplementasi di sekolah masih meraba-raba arah tujuannya. Dan yang paling jelas terlihat salah satu indikator kegagalan dunia pendidikan kita 
yaitu masih rendahnya lulusan yang mampu menembus pasar kerja sehingga meningkatkan angka pengangguran intelektual.

Sebagai praktisi pendidikan jika masalah ini timbul, yang paling kita cermati bersama adalah bagaimana proses belajar mengajamya apakah sudah efektif atau belum efektif, karena masih bauyak siswa yang tawuran pada saat jam efektif belajar, guru yang kerja merangkap beberapa sekolah, orangtua yang kurang peduli pada pendidikan anaknya, namun dari hal-hal tersebut sekali lagi yang paling kita cermati adalah proses belajarnya.

Kemendikbud sebagai salah satu kementerian yang bertanggungiawab mengatasi permasalahan tersebut di atas juga sebenarnya tidak tinggal diam, dalam arti secara terus menerus memperbaiki mutu pendidikan di semua jenis dan jenjang pendidikan, termasuk menggulirkan konsep Manajemen Berbasis Sekolah (School Based Management) yang sudah diujicobakan sejak tahun 1999 karena selaras dengan desentralisasi pemerintahan dalam era otoromi pendidikan. MBS merupakan alternatif pendekatan dalam mengelola pendidikan yang difokuskan pada pernberian otonomi yang lebih luas pada sekolah untuk mengelola dirinya sendiri. Sasarannya adalah peningkatan mutu sekolah tersebut.

MBS adalah wujud dari reformasi pendidikan, yang menginginkan adanya perubahan dari kondisi yang kurang baik menuju kondisi yang lebih baik, dan memahami otonomi pendidikan serta menciptakan kemandirian sekolah adalah salah satu prasyarat dalam menuju sekolah yang berbasis masyarakat. Untuk itu kepala sekolah sebagai pimpinan tertinggi di sekolah haruslah seseorang yang benar-benar mempunyai wawasan, pemahaman, pengetahuan dan keterampilan sebagai seorang wirausaha (entrepreneurship), karena pengetahuan entrepreneurship merupakan jiwa/ rohnya dalam pelaksanaannya yang sangat mempengaruhi efektivitas MBS.

Pada tahun 2000 sudah banyak sekolah yang melaksanakan MBS, tetapi belum ada hasil penelitian yang mengetahui pelaksanaannya apakah sudah berjalan efektif atau tidak? Karena sepertinya MBS ini sudah dilupakan stakeholders begitu saja.

Tertarik akan hal tersebut maka diadakan penelitian ini di beberapa SD Negeri yang menjadi pilot project MBS di Kota Tangerang, karena secara empirik rata-rata sekolah-sekolah tersebut mengalami kemajuan yang sangat pesat baik dari segi kualitas edukatif maupun kualitas non edukatif (manajemennya), hal inilah yang menjadi dasar mengapa penelitian efektivitas MBS ini dilakukan.

\section{Permasalahan}

Berdasarkan latar belakang masalah di atas, dirumuskan masalah "apakah terdapat hubungan antara pengetahuan entrepreneurship kepala sekolah dengan efektivitas Manajemen Berbasis Sekolah di Kota Tangerang?”

\section{Maksud dan Tujuan Maksud}

Maksud dari penelitian adalah untuk memberikan pemahaman dan masukan kepada stakeholders tentang bagaimana cara meningkatkan efektivitas pengelolaan sekolah dengan pendekatan manajemen berbasis sekolah.

\section{Tujuan}

Tujuan penelitian ini adalah mewujudkan strategi untuk meningkatkan efektivitas MBS dengau mengoptimalisasi peran kepala sekolah.

\section{KERANGKA TEORETIK Efektivitas MBS}

\section{a. Hakekat Efektivitas MBS}

Efektivitas (effectivenes) hakekatnya merujuk kepada kemampuan untuk mencapai tujuan secara memadai. Biasanya kata efektif selalu diikuti kata efesien. A. Dale Timpe dalam buku "la waktu" mendefinisikan efektif berarti melakukan hal yang benar dan mengerjakan hal yang memberikan hasil. Cascio dan Awad, mengatakan efektivitas sebagai tingkat ketepatan hasil kerja yang didasarkan atas rencana yang sudah ditetapkan.

Hal tersebut senada dengan Ying Cheong Cheng dalam buku School Effectiveiess \& School Based Management, mengatakan bahwa efektivitas adalah sebuah kriteria evaluasi tentang pengukuran keberhasilan dari suatu kebijaksanaan atau perencanaan dibandingkan dengan akibat atau hasil yang diharapkan.

Lebih luas lagi Anthony dan Young mengatakan bahwa efektivitas tampak pada hubungan antara output yang dihasilkan oleh yang bertanggungiawab dengan tujuan-tujuan yang ditetapkan. Pernyataan ini mengisyaratkan bahwa efektivitas sangat ditentukan oleh pihak-pihak yang paling bertanggungjawab dalam menghasilkan kerja sesuai dengan sasaran yang telah ditentukan. Jika pihak yang bertanggungjawab dapat menghasilkan output yang sesuai dengan sasaran yang telah ditetapkan, maka berarti ia tidak bekerja 
secara efektif, sebaliknya apabila output yang dihasilkannya tidak sesuai atau tidak mencapai sasaran yang telah ditetapkan berarti kerjanya tidak efektif. Dan efektivitas MBS sangat dipengaruhi oleh pimpinan dalam hal ini kepala sekolah.

Dari uraian di atas dapat ditarik benang merah efektivitas adalah keberhasilan yang ditandai oleh adanya kesesuaian antara rencana yang telah dibuat dengan hasil yang dicapai.

Priscilla W. mengatakan dalam buku Organizing for Succesful school Based Management, bahwa manajemen berbasis sekolah merupakan salah satu agenda dalam reformasi pendidikan pada beberapa dasa warsa terakhir. Hal ini disebabkan penyelenggaraan pendidikan nasional dilakukan dan diatur secara birokratik, sehingga posisi sekolah sebagai penyelenggara pendidikan sangat tergantung pada peraturan, instruksi dan berbagai keputusan birokrasi yang sangat panjang. Disamping itu, keputusan birokrasi kadang tidak sesuai dengan kondisi sekolah setempat. Dengan demikian sekolah kehilangan kemandirian, motivasi, dan inisiatif untuk mengembangkan dan memajukan lembaganya termasuk memperbaiki mutu pendidikan.

Fasli Jalal dan Dedi Supriadi mendefinisikan MBS sebagai salah satu pengelolaan sekolah yang bertumpu pada kepala sekolah, staf, dan masyarakat serta jauh dari birokrasi yang sentralistik, sehingga sekolah punya kebebasan untuk menentukan apa yang perlu diajarkan dengan mengelola sumber daya secara kreatif dan inovatif.

Sejalan dengan pendapat di atas, hal ini dapat membantah pendapat bahwa keberhasilan program pembarngunan sekolah yang ada hanya lebih menekankan pada penyediaan input pendidikan, seperti: guru, kurikulum, fasilitas pendidikan, bu$\mathrm{ku}$, alat peraga, dan sumber belajar lainnya. Asumsi yang mendasari kebijakan bahwa peningkatan mutu pendidikan akan terjadi dengan sendirinya apabila input pendidikan terpenuhi. Dalam kenyataannya, asumsi ini meleset karena input tanpa proses manajemen yang baik tidak akan menghasilkan output yang diharapkan.

Audrey J. Noble juga mengatakan MBS lebih merujuk pada representasi proses pengambilan keputusan dimana seluruh anggota kelompok berpartisipasi secara seimbang. MBS merupakan strategi untuk meningkatkan mutu pendidikan dengan mengalihkan kewenangan pembuatan keputusan yang signifikan dari pemerintah pusat kepemerintah daerah ke masingmasing sekolah. Dengan demikian MBS adalah suatu bentuk strategi pengelolaan sekolah dalam rangka meningkatkan mutu pendidikan dengan cara memberikan otonomi yang lebih luas pada sekolah.

Berdasarkan teori-teori di atas dapat disimpulkan bahwa efektivitas MBS adalah ketercapaian sasaran yang telah direncanakan dengan hasil yang diharapkan oleh semua pihak yang berkepentingan, dengan cara melakukan perubahan dalam pengelolaan sekolah sehingga dapat mengembangkan sekolahnya menjadi sekolah yang bermutu.

b. Karakteristik MBS

Rumtini dan Jiyono mengutip dari Focus on School, mengemukakan ciri-ciri MBS sebagai berikut :

\begin{tabular}{|c|c|c|c|}
\hline \multicolumn{4}{|c|}{ Tabel 1. Ciri-ciri Manajemen Berbasis Sekolah } \\
\hline $\begin{array}{l}\text { Organisasi } \\
\text { Sekolah }\end{array}$ & $\begin{array}{l}\text { Proses Belajar } \\
\text { Mengajar }\end{array}$ & SDM & $\begin{array}{c}\text { Sumber Daya } \\
\text { dan Administrasi }\end{array}$ \\
\hline $\begin{array}{l}\text { 1. Kepemimpinan } \\
\text { Transforma- } \\
\text { sional. } \\
\text { 2. Menyusun ren- } \\
\text { cana/kebijakan. } \\
\text { 3. Mengelola } \\
\text { kegiatan opera- } \\
\text { sional. } \\
\text { 4. Komunikasi de- } \\
\text { ngan masyarakat } \\
\text { efektif. } \\
\text { 5. Akuntabilitas } \\
\text { tinggi }\end{array}$ & $\begin{array}{l}\text { 1. Meningkatkan } \\
\text { kualitas belajar. } \\
\text { 2. Mengembang- } \\
\text { kan kurikulum } \\
\text { yang cocok dan } \\
\text { tanggap terha- } \\
\text { dap kebutuhan } \\
\text { siswa dan } \\
\text { masyarakat } \\
\text { sekolah. } \\
\text { 3. Menyelenggara- } \\
\text { kan pengajaran } \\
\text { yang efektif. } \\
\text { 4. Menyediakan } \\
\text { program pe- } \\
\text { ngembangan } \\
\text { yang diperlukan } \\
\text { siswa. }\end{array}$ & $\begin{array}{l}\text { 1. Memberda- } \\
\text { yakan staf dan } \\
\text { menempatkan } \\
\text { personel yang } \\
\text { dapat diperlu- } \\
\text { kan dan mela- } \\
\text { yani keperluan. } \\
\text { 2. Memilih staf } \\
\text { yang memiliki } \\
\text { wawasan } \\
\text { "School Based } \\
\text { Management". } \\
\text { 3. Menyediakan } \\
\text { mengelola } \\
\text { kesejateraan } \\
\text { staff. } \\
\text { 4. Menyelenggara- } \\
\text { kan dukungan } \\
\text { forum/diskusi } \\
\text { untuk memba- } \\
\text { has kemajuan }\end{array}$ & $\begin{array}{l}\text { 1. Mengidentifika- } \\
\text { si sumber daya } \\
\text { yg diperlukan } \\
\text { dan meng-alo- } \\
\text { kasikan sumber } \\
\text { daya tersebut } \\
\text { sesuai dengan } \\
\text { kebutuhan. } \\
\text { 2. Mengelola dana } \\
\text { sekolah. } \\
\text { 3. Menyediakan } \\
\text { dukungan } \\
\text { administratif. } \\
\text { 4. Mengelola dan } \\
\text { memelihara } \\
\text { gedung dan } \\
\text { sarana lainnya. }\end{array}$ \\
\hline
\end{tabular}

Sedangkan fungsi-fungsi yang didesentralisasikan ke sekolah adalah:1) perencanaan dan evaluasi program sekolah; 2) pengelolaan kurikulum; 3) pengelolaan PBM; 4) pengelolaan ketenagaan; 4)pengelolaan peralatan dan perlengkapan; 5) pengelolaan keuangan; 6) pelayanan siswa; 7) humas; dan 8) pengelolaan iklim sekolah.

Direktorat SLTP, Ditjen Dikdasmen Depdiknas (2002) dikutip Hadiyanto, membuat rambu-rambu karakteristik sekolah yang efektif yang diharapkan dapat dicapai oleh sekolah yang menjadi rintisan proyek Manajemen Peningkatan Mutu Berbasis Sekolah (MPMBS), yaitu:

1) Pengelolaan belajar mengajar efektivi- 
tasnya tinggi;

2) Kepemimpinan sekolah kuat;

3) Lingkungan sekolah aman dan tertib;

4) Pengelolaan tenaga kependidikan efektif;

5) Memiliki budaya mutu;

6) Memiliki teamwork yang kompak, cerdas dan dinamis;

7) Memiliki kewenangan (kemandirian);

8) Partisipasi warga sekolah dan masyarakat tinggi;

9) Manajemen terbuka;

10) Memiliki kemauan berubah;

11) Melakukan evaluasi dan perbaikan berkelanjutan;

12) Responsif dan antisipasif terhadap kebutuhan;

13) Komunikasi baik;

14) Memiliki akuntabilitas; dan

15) Mampu menjaga subtainabilitas.

c. Peran Kepala Sekolah dalam efektivitas MBS

Agar efektivitas MBS tinggi kepala sekolah memiliki peran antara lain sebagai:

1) Dinamisator;

2) Pengambil keputusan (Decision Maker); yakni:

a). Pemrakarsa (Entrepreneur);

b). Penghalaugangguan(Disturbance handler);

c). Pembagi sumber (Recource allocator);

d). Negosiator;

3) Kreator; dan

4) Orang yang senantiasa belajar dan melakukan pembelajaran.

\section{Pengetahuan Entrepreneurship}

a. Hakikat Pengetahuan Entrepreneurship

Plato mengatakan bahwa pengetahuan sebagai keyakinan seseorang akan suatu hal. Suriasumantri mendefinisikan bahwa pengetahuan adalah merupakan segenap apa yang diketahui oleh manusia tentang suatu obyek tertentu termasuk didalamnya ilmu, jadi ilmu merupakan bagian dari pengetahuan yang diketahui manusia disamping pengetahuan yang lainnya, seperti seni dan agama.

Namun menurut Kirby, pengetahuan merupakan "struktur konseptual yang dibangun dari pengalaman kita sendiri dan diuji kembali dalam keadaan yang sebenarnya. "Manusia memperoleh pengetahuan melalui panca inderanya. Melalui indera yang dimiliki, manusia melihat, mendengar, membau, merasakan, dan meraba suatu obyek yang ada di sekitarnya.
Informasi yang diperoleh melalui proses pengindera tersebut kemudian dapat melekat di memori, yang kemudian menjadi pengetahuan.

Lebih luas lagi Desler mengatakan "pengetahuan adalah informasi yang telah disaring melalui kegiatan belajar atau penelitian dan djperkaya melalui penilaian dan pengalaman." Demikian juga Wolfoolk, mengatakan "pengetahuan adalah hasil dari kegiatan belajar, pengetahuan lebih dari sekedar produk akhir dari kegiatan: pembelajaran sebelumnya, tetapi menjadi pedoman pembelajaran baru." Definisi ini menunjukkan bahwa manusia akan memperoleh pengetahuan jika ia melakukan kegiatan belajar dan pengetahuan yang dimilikinya sebagai pedoman untuk mempelajari hal-hal baru.

Dari pendapat di atas dapat disimpulkan bahwa pengetahuan adalah segenap informasi yang diketahui tentang suatu obyek yang dimiliki seseorang baik diperoleh melalui pendidikan formal maupun nonformal.

Entrepreneurship berasal dari Bahasa Perancis, secara epistemologis entrepreneurship hakikatnya adalah suatu kemampuan dalam berfikir kreatif dan berprilaku inovatif yang dijadikan dasar sumber daya, tenaga penggerak, tujuan, siasat, kiat dalam menghadapi tantangan hidup. Entrepreneur atau wirausaha adalah orang-orang yang mempunyai kemampuan melihat dan menilai kesempatan-kesempatan guna mengambil keuntungan dari padanya dan mengambil tindakan yang tepat guna memastikan sukses.

Dalam konteks manajemen, Marzuki Usman mengatakan bahwa entrepreneur adalah seseorang memiliki kemampuan dalam menggunakan sumber daya financial (money), bahan mentah (materials), dan tenaga kerja (labour), untuk menghasilkan produk baru, bisnis baru, proses produksi, atau pengembangan organisasi usaha. Dan seorang wirausahawan selalu mencari perubahan, menanggapinya dan memanfaatkannya sebagai peluang.

Dalam Bahasa Indonesia, entrepreneurship adalah kewirausahaan. Istilah wirausaha lebih dikenal dengan istilah wiraswasta. Wiraswasta berasal dari kata "wira" dan "swasta", wira berarti berani, ulama, atau perkasa. Swasta paduan dari kata "swa" dan "sta", swa artinya sendiri, sta artinya berdiri. Swasta dapat diartikan sebagai berdiri sendiri menurut kekuatan 
sendiri. Jika dipadukan wiraswata adalah keberanian, keutamaan dan keperkasaan dalam memenuhi kebutuhan serta memecahkan permasalahan hidup dengan kekuatan yang ada pada diri sendiri.

Dari berbagai pendapat di atas, dapat diambil kesimpulan bahwa entrepreneurship adalah suatu kemampuan dalam menggunakan sumber daya yang ada, dengan cara berpikir kreatif dan inovatif untuk mengembangkan dan. menghasilkan sesuatu yang berbeda dari sebelumnya dengan kemampuan sendiri.

b. Karakteristik Entrepreneurship

Ciri-ciri dan watak kewirausahaan menurut Geofrey yaitu percaya diri, berorientasi pada tugas dan hasil, mau mengambil resiko dan suka tantangan, kepemimpinan, keorisinilan, dan berorientasi ke masa depan.

Arthur mengemukakan karakteristik wirausaha dalam bentuk nilai-nilai dan perilaku kewirausahaan yaitu commitment; moderate risk; seeing opportunities; objectivity; feedback; optimism; money and proactive management. Demikian juga Wasty mengemukakan ciri-ciri manusia wiraswasta adalah moral yang tinggi, sikap mental wiraswasta bisnis, mengumpulkan sumber-sumber daya yang dibutuhkan, kepekaan terhadap arti lingkungan dan keterampilan wiraswasta. Lebih luas lagi M. Scarborough dan Thomas W.Zimmerei dikutip Suryana mengidentifikasi 8 karakteristik entrepreneur yaitu desire forresponsibility; preperence for mode 1 atrisk; confidence intheir ability tosuccess; desire for immediate feedback; hight level of energy; future orientation; skill organizing; and value of achievement over money.

\section{Kerangka Berpikir}

Berdasarkan kerangka teori dan sintesis teoritik yang dikemukakan di atas maka dapat dibuat kerangka berfikir sebagai berikut:

Tabel 2. Kerangka Berpikir Hubungan Pengetahuan Entrepreneurship dengan Efektivitas MBS

\begin{tabular}{|c|c|c|}
\hline $\begin{array}{l}\text { Kemampuan } \\
\text { Kepsek }\end{array}$ & $\begin{array}{c}\text { Efektivitas MBS } \\
\text { Tinggi }\end{array}$ & $\begin{array}{l}\text { Entrepeneursip } \\
\text { Tinggi }\end{array}$ \\
\hline $\begin{array}{l}\text { - Tidak tergantunga } \\
\text { pada kebijakan } \\
\text { atasan. } \\
\text { - Mampu men- } \\
\text { gambil keputusan } \\
\text { dengan cepat. } \\
\text { - Mempunyai } \\
\text { prioritas menin- } \\
\text { gkatkan kualitas } \\
\text { lulusan. }\end{array}$ & $\begin{array}{l}\text { - } \text { Mengembangkan } \\
\text { kurikulum yang } \\
\text { sesuai dengan } \\
\text { kebutuhan siswa } \\
\text { dan masyarakat. } \\
\text { - Melaksanakan } \\
\text { program kerja } \\
\text { sesuai rencana. }\end{array}$ & $\begin{array}{l}\text { - Kemaandirian } \\
\text { tinggi. } \\
\text { - Percaya diri. } \\
\text { - Orientasi pada } \\
\text { tugas dan hasil } \\
\text { tinggi. } \\
\text { - Berani mengambil } \\
\text { resiko. } \\
\text { - Suka tantangan. }\end{array}$ \\
\hline
\end{tabular}

\begin{tabular}{|c|c|c|}
\hline $\begin{array}{l}\text { Kemampuan } \\
\text { Kepsek }\end{array}$ & $\begin{array}{l}\text { Efektivitas MBS } \\
\text { Tinggi }\end{array}$ & $\begin{array}{l}\text { Entrepeneursip } \\
\text { Tinggi }\end{array}$ \\
\hline $\begin{array}{l}\text { - Berami berkorban } \\
\text { demi tercapainya } \\
\text { tujuan sekolah. } \\
\text { - Menghadapi } \\
\text { hambatan sebagai } \\
\text { tantangan. } \\
\text { - Banyak ide-ide. } \\
\text { - Menganggap } \\
\text { peluang adalah } \\
\text { kesempatan baik. } \\
\text { - Punya visi, misi } \\
\text { tujuan, sasaran } \\
\text { dan target yang } \\
\text { logis. }\end{array}$ & $\begin{array}{l}\text { - Melibatkan guru, } \\
\text { orang tua dan } \\
\text { masyarakat. } \\
\text { - Menerapkan } \\
\text { kepemimpinan } \\
\text { partisipatif. } \\
\text { - Menerapkan } \\
\text { manajemen secara } \\
\text { sistematik dan } \\
\text { sistemik. } \\
\text { - Responsif ter- } \\
\text { hadap saran dan } \\
\text { kritik dari dalam } \\
\text { dan luar. } \\
\text { - Mengelola sumber } \\
\text { daya dengan } \\
\text { benar dan mem- } \\
\text { berdayakan SDM } \\
\text { dengan tepat. } \\
\text { - Mengikuti kom- } \\
\text { petisi di semua } \\
\text { tingkatan. } \\
\text { - Melaksanakan } \\
\text { visi, misi, tujuan, } \\
\text { sasaran dan target } \\
\text { dengan efektif. }\end{array}$ & 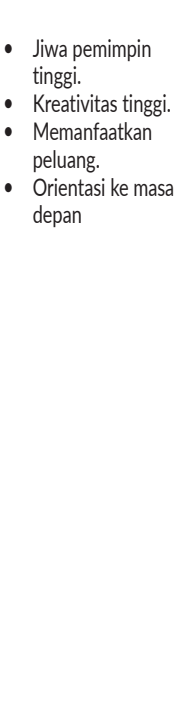 \\
\hline
\end{tabular}

\section{METODE PENELITIAN \\ Desain Penelitian}

Penelitian ini menggunakan metode survei dengan pendekatan korelational dimana peneliti tidak memberikan treatment terhadap variabel bebas, namun peneliti tinggal melakukan pengukuran, mengambil dan mengumpulkan data dari peristiwa yang telah berlangsung, sejak uji coba MBS tahun 2000 dan diberlakukannya MBS di SD Negeri Kota Tangerang.

\section{Populasi dan Sampel}

Populasi dalam penelitian ini adalah seluruh kepala sekolah SD Negeri dari 13 kecamatan yang ada di Kota Tangerang. Sampel dalam penelitian ini adalah kepala sekolah di SD Negeri unggulan yang ada di Kota Tangerang yang sudah melaksanakan MBS. Sampel dalam penelitian ini adalah 30 kepala sekolah di SD negeri unggulan yang ada di Kota Tangerang.

Teknik pengambilan sampel yang telah melaksanakan MBS. Sampel dalam peneliti ini dilakukan dengan cara stratified proporsional random sampling. Responden dalam penelitian ini adalah kepala sekolah baik untuk variabel bebas maupun terikat.

\section{Waktu dan Tempat}

Peneltian ini dilakukan bulan September 2017 dan tempat penelitian dilakukan di 30 SD Negeri Unggulan di Kota Tangerang.

\section{Teknik Analisis Data}

Analisis data dilakukan dengan menggunakan rumus stastistik (1) deskripsi data meliputi: rerata, rentangan, varians, dan modus, 
serta dilengkapi dengan tabel distribusi frekuensi dan histogram; (2) pengujian prasyarat analissis meliputi; homogenitas variansi sampel, dan uji normalitas galat regresi sederhana, korelasi sederhana, serta dengan menggunakan korelasi dan regresi.

Adapun hipotesis statistik sebagai berikut:

Ho : $\rho y=0$

Ho : $\rho y>0$

\section{HASIL PENELITIAN \\ Deskripsi Data}

1. Efektivitas Manajemen Berbasis Sekolah.

Untuk mengukur variabel Efektivitas MBS di SD Negeri Kota Tangerang Banten digunakan instrumen sebanyak 40 butir, dengan skor teoritik terendah 40, skor tertinggi 160 , dan skor rata-rata 100. Dari hasil penelitian dan pengolahan data diperoleh skor empirik terendah 108, skor tertinggi 153, dan skor rata-rata 137,90. Selain itu diperoleh modus 143,06, median 139,50, standar deviasi 21,59, dan variansi sebesar 134,23.

Jika skor responden dikelompokkan ke dalam distribusi frekuensi, diperoleh 6 orang (20\%) berada di dalam kelompok rata-rata, 9 orang (30\%) berada di bawah kelompok rata-rata, dan 15 orang (70\%) berada di atas rata-rata. Ini mengindikasikan bahwa 21 orang (70\%) memiliki efektivitas MBS dalam kelompok rata-rata atau lebih tinggi dari kelompok rata-rata.

2. Pengetahuan Entrepreneurship Kepala Sekolah.

Untuk mengukur pengetahuan entrepreneurship kepala sekolah digunakan tes sebanyak 30 soal, dengan skor terendah 0 , tertinggi 30, dan skor rata-rata 15 , dari hasil penelitian dan pengolahan data diperoleh skor empirik terendah 12, skor tertinggi 29, berdasarkan hasil analisis deskriptif diperoleh skor rata-rata empirik 21,87 , modus 24,70 , median 22,50, standar deviasi 4,66 dan variansi 21,71.

Jika skor responden dikelompokkan ke dalam distribusi frekuensi, diperoleh 6 orang (20\%) berada dalam kelompok rata-rata, 11 orang $(36,67 \%)$ berada di bawah kelompok rata-rata, dan 13 orang (43,33 \%) berada di atas rata-rata. Data ini mengindikasikan bahwa sebagian besar yaitu 19 orang $(93,33 \%)$ kepala sekolah memiliki tingkat pengetahuan entrepreneuship dengan skor rata-rata atau lebih tinggi dari kelompok rata-rata.

\section{Pengujian Prasyarat Analisis}

1. Uji Normalitas Galat Regresi $Y$ atas $X$

Dari hasil perhitungan berdasrkan galat regresi $\mathrm{Y}$ atas $\mathrm{X}$, diperoleh harga maksimum Uji Liliefors yaitu Lo - 0,15<Kritis $\mathrm{Lo}=0,161$, maka disimpulkan bahwa galat regresi $\mathrm{Y}$ atas $\mathrm{X}$, berdistribusi normal. Dalam hal ini menunjukkan bahwa persyaratan normalitas data untuk regresi linier sederhana $\mathrm{Y}$ atas $\mathrm{X}$ dipenuhi.

2. Uji Homogenitas Varians Populasi Regresi $\mathrm{Y}$ atas $\mathrm{X}$

Dari hasil perhitungan berdasarkan galat regresi $\mathrm{Y}$ atas $\mathrm{X}$, diperoleh $\mathrm{X}^{2}$ tabel $=26,429$ pada taraf nyata $\alpha=0,05$ dan derajat kebebasan $(\mathrm{db})=16$. Karena nilai $\mathrm{X}^{2}$ hitung $=11,40<\mathrm{X}^{2}$ tabel $=26,429$, maka disimpulkan bahwa varians regresi $\mathrm{Y}$ atas $\mathrm{X}$ berasal dari populasi yang homogen.

\section{Pengujian Hipotesis}

Hasil pengujian persyaratan analisis data yang telah dikemukakan di atas memberikan kesimpulan bahwa data penelitian ini berasal dari populasi berdistribusi normal dan memiliki varians yang homogen, sehingga layak untuk dilakukan analisis lebih lanjut, yaitu pengujian terhadap hipotesis penelitian.

Berdasarkan hasil perhitungan melalui regresi linier sederhana diperoleh adanya hubungan positif antara Pengetahuan Entrepeneurship Kepala Sekolah (X) dengan Efektivitas MBS (Y) yang dinyatakan dalam bentuk regresi $\square=106,48+1,44 \mathrm{X}$.

Sebelum digunakan untuk menarik kesimpulan dan membuat prediksi, persamaan regresi yang diperoleh terlebih dahulu harus memenuhi syarat keberartian dan kelinieran regresi dilakukan dengan uji $\mathrm{F}$, dengan hasil sebagai berikut.

\begin{tabular}{|c|c|c|c|c|c|c|}
\hline \multicolumn{7}{|c|}{$\begin{array}{l}\text { Tabel 3. Anava untuk Uji Keberartian dan Kelinieran } \\
\text { Persamaan Regresi Y = 106,48+1,44X }\end{array}$} \\
\hline \multirow[b]{2}{*}{$\begin{array}{l}\text { Sumber } \\
\text { Varians }\end{array}$} & \multirow[b]{2}{*}{$\mathrm{db}$} & \multirow[b]{2}{*}{ RJK } & \multirow[b]{2}{*}{ Co } & \multirow[b]{2}{*}{$F_{\text {hitung }}$} & \multicolumn{2}{|c|}{$F_{\text {tabel }}$} \\
\hline & & & & & $\begin{array}{c}a= \\
0,05\end{array}$ & $a=0,01$ \\
\hline Total & 30 & 574385 & & & & \\
\hline Regresi (a) & 1 & 570492,3 & 570492,3 & $14,04^{* *}$ & 4,20 & 7,64 \\
\hline Regresi (bla) & 1 & 1299,99 & 1299,99 & & & \\
\hline Regresi (s) & 28 & 2592,71 & 92,60 & & & \\
\hline $\begin{array}{l}\text { Tuna } \mid \text { Cocok } \\
\text { (TC) }\end{array}$ & 15 & 1347,38 & 89,83 & $0,94 \mathrm{~ns}$ & 2,53 & 3,86 \\
\hline Galat & 13 & 1245,33 & 95,79 & & & \\
\hline $\begin{array}{l}\text { Keterangan : } \\
{ }^{* *}: \text { reg } \\
\text { ns }: \text { per } \\
\text { JK }: \text { jum } \\
\text { db }: \text { der } \\
\text { RJK : }\end{array}$ & $\begin{array}{l}\text { angat } \\
\text { an re } \\
\text { kuadra } \\
\text { kebeb } \\
\text { Imlah }\end{array}$ & $\begin{array}{l}\text { nifikan } \\
\text { si linier } \\
\text { uuadrat } \\
\text { n } \\
\text { drat }\end{array}$ & & & & \\
\hline
\end{tabular}


Berdasarkan Anava di atas, menunjukkan nilai $\mathrm{F}_{\text {hitung }}$ (bIa) $=14,04>\mathrm{F}_{\text {tabel }}=4,20$ pada $\alpha=0,05$ sehingga dapat disimpulkan bahwa persamaan regresi $\mathrm{Y}$ atas $\mathrm{X}$ adalah signifikan, yang berarti terdapat hubungan positif dan berarti antara Efektivitas MBS (Y) dengan Pengetahuan Entrepreneurship Kepala Sekolah (X) melalui persamaan regresi $Y=106,48+1,44 X$. Dan persamaan regresi tersebut berbentuk linier yang dibuktikan oleh nilai $\mathrm{F}_{\text {hitung }}(\mathrm{TC})=0,94<\mathrm{F}_{\text {tabel }}=$ 2,33 pada taraf nyata $\alpha=0,05$.

Persamaan regresi $\square=106,48+1,44 \mathrm{X}$ mengandung makna bahwa setiap kenaikan satu skor Pengetahuan Entrepreneurship Kepala Sekolah (X) cenderung diikuti oleh kenaikan skor Efektivitas MBS (Y) sebesar 1,44 satuan. Makin tinggi skor Pengetahuan Entrepreneurship Kepala Sekolah makin tinggi pula skor Efektivitas MBS.

Sedangkan kekuatan hubungan antara Pengetahuan Entrepreneurship Kepala Sekolah dengan Efektivitas MBS dinyatakan dalam bentuk koefesien korelasi product moment ry= 0,58. Nilai statistik untuk koefesien korelasi untuk $\mathrm{t}_{\text {hitung }}=3,75$. Sedangkan $\mathrm{t}$ tabel pada taraf nyata $\alpha=0,05$ dan $\mathrm{db}-28$ adalah 1,70.

Karena nilai $\mathrm{t}_{\text {hitung }}=3,75>\mathrm{t}_{\text {tabel }}=1,70$ maka dapat disimpulkan bahwa koefesien korelasi antara variabel Pengetahuan Entrepreneurship Kepala Sekolah dengan Efektivitas MBS di SD Negeri Kota Tangerang Banten adalah signifikan. Dengan demikian terdapat hubungan positif antara variabel Pengetahuan Entrepreneurship Kepala Sekolah dengan Efektivitas MBS di SD Negeri Kota Tangerang, Banten. Hubungan yang demikian diartikan bahwa semakin tinggi skor Pengetahuan Entrepreneurship Kepala Sekolah, maka cenderung tinggi pula skor Efektivitas MBS.

Besarnya kontribusi variabel Pengetahuan Entrepreneurship Kepala Sekolah terhadap variabel Efektivitas MBS di Kota Tangerang Banten ditunjukkan oleh nilai koefesien determinasi $\mathrm{r}^{2} \mathrm{x} 100 \%=33,40$. Ini dapat diartikan bahwa sebesar $33,40 \%$ kontribusi varabel Pengetahuan Entrepreneurship Kepala Sekolah terhadap Efektivitas MBS.

\section{SIMPULAN}

\section{Kesimpulan}

Berdasarkan pembahasan hasil penelitian, maka dapat ditemukan hasil penelitian sebagai berikut.

1. Terdapat hubungan positif antara Pengetahuan Entrepreneurship Kepala Sekolah (X) dengan Efektivitas MBS (Y) yang ditunjukkan dalam bentuk persamaan regresi $\square=106,48+1,44$ X yang signifikan. Artinya setiap peningkatan satu skor Pengetahuan Entrepreneurship (X) mengakibatkan kenaikan skor Efektivitas MBS (Y) sebesar 1,44 dari konstanta 106,48.

2. Besarnya nilai korelasi yang menyatakan hubungan antara Pengetahuan Entrepreneurship (X) dengan Efektivitas MBS (Y) dinyatakan sebesar ry $=0,38$ yang signifikan. Hal ini menunjukkan jika Pengetahuan Entrepreneurship (X) ditingkatkan, maka Efektivitas MBS (Y) meningkat. Demikian pula sebaliknya, jika Pengetahuan Entrepreneurship Kepala Sekolah (X) rendah, maka Efektivitas MBS (Y) menurun.

3. Besarnya koefesien determinasi sebesar $r^{2}=0,3340$ menunjukkan bahwa 33,40\% efektivitas MBS dipengaruhi oleh Pengetahuan Entrepreneurship Kepala Sekolah sedangkan $66,60 \%$ dipengaruhi oleh variabel lainnya.

\section{Saran}

Berdasarkan hasil penelitian dan kesimpulan di atas, maka selanjutnya peneliti ingin memberikan masukan guna untuk perbaikan pada masa mendatang. Adapun saransaran peneliti sebagai berikut .

1. Untuk Mendikbud, dalam menyusun uji kompetensi atau tes akademik maupun psikotes bagi calon kepala sekolah perlu memasukan variabel yang berhubungan dengan Pengetahuan Entrepreneurship atau kewirausahaan sebagai wawasan para kepala sekolah dan berguna setelah menghadapi praktek di lapangan.

2. Untuk kepala sekolah perlu pembiasaan agar mau menumbuhkembangkan jiwa entrepreneur dalam dirinya dan kepemimpinan di sekolah sehingga hambatan yang dihadapi terutama untuk pelaksanakan MBS dapat diatasi dengan baik.

3. Untuk kepala sekolah perlu menguasai juga prinsip-prinsip pengelolaan MBS agar kualitas pendidikan kita dapat ditingkatkan secara terus menerus dengan merangkul masyarakat sebagai basic dalam membuat program kerja yang sistemik dan sistematik.

4. Untuk para peneliti, perlu dilakukan penelitian lebih lanjut terhadap Efektivitas MBS ini, karena masih banyak variabel lain yang mempengaruhi Efektivitas MBS.

\section{DAFTAR PUSTAKA}

Anthony, Robert N., dan David W. Young.1994. Management Control in Nonprofit 
Organizations. USA: Ricard D. Irwin Inc.

Balitbang Depdiknas. 2001. Manajemen Peningkatan Mutu Berbasis Sekolah, Konsep dan Pelaksanaan. Jakarta: Dirjen Pendidikan Dasar dan Menengah, Direktorat SLTP.

Casein, WF. Dan E.M Awad. 1981. Human Recources Management, An Information Systems Approach. Virginia: Reston Publishing, Co.

Chapman, Judith. 1990. School Based Decision Making and Management. London: The Palmer Press.

Cheng Ying Cheong. 1996. School Efectiveness School Base Management. London: Palmers Press.

Depdikbud. 1995. Kamus Besar Bahasa Indonesia. Jakarta: PN Balai Pustaka.

Drucker, Peter F. 1995. Inovasi dan Kewiraswastaan, Praktek dan Dasar-dasar. Terjemahan Rusjdi Naib. Jakarta: Erlangga.

Deseler Gary. 1995. Managing Organization: An Era Of Change. Forth Worth, The Drylan Press.

Duhou Ibtisan Abou. 1994. School Based Management. Paris: UNESCO International Institute For Education Planning..

Erchols Jhon M. \& Shadly Hasan. 1996. Kamus Inggris Indonesia. Jakarta: PT. Gramedia.

Hadiyanto. 2004. MencariSosokDesentralisasi Manajemen Pendidikan di Indonesia. Jakarta: Rhineka Cipta.

Kirby Jhon R. 1984. Cognitive Strategies and Educational Performance. Orlando: Academic Press Inc.

Meredith Geofrey G. 2000. Kewirausahaan : Teori dan Praktek. Jakarta: PPM.

Mohram, Susan Albert, Prascilla Wohlstetter and Associate. 1994. School Based Management: Organizing for High Performance. San Francisco: Jossey Bass.

Noble Audrey J. 1989. School Based Management. New York: Associate for Education and Policy Analysis.

Plato, Knowlagde. 1995. http://www.philosophy. Nevadis Knowlagde/Patohtml.

Rumtini dan Jiyono. 1999. Manajemen Berbasis Sekolah: Konsep dan Kemungkinan Strategi Pelaksanaannya di Indonesia. Jurnal Pendidikan dan Kebudayaan, No. 017.

Soemanto, Wasty. 1993. Pendidikan Wiraswasta. Jakarta, Bumi Aksara.

Suryana. 2003. Kewirausahaan: Pedoman Praktis, Kiat dan Proses Menuju Sukses. Jakarta, Salemba Empat.

Timpe, A. Dale. 1999. Sesi Manajemen Sumber Daya Manusia: Mengelola Waktu. Jakarta: PT. Gramedia.
Usman Marzuki. 1997. Kewirausahaan dalam Birokrasi Salah Satu Langkah Antisipatif Menghadapi Globalisasi. Makalah Seminar, Jatinangor: IKOPIN.

Wahjosumidjo. 2001. Kepemimpinan Kepala Sekolah. Jakarta: PT. Raja Grafindo Persada.

Wohlstetter Priscilla et. all. 1997. Orgaozing for Succesfull School Based Management. Alexandria: Association for Supervisison and Curriculum Development.. 